\title{
Reseña. Lucía Guerra Cunningham, La ciudad ajena: Subjetividades de origen Mapuche en el espacio urbano. Santiago: Ceibo Ediciones, 2014. Premio Casa de las Américas (2013)
}

El 19 de septiembre de 2014, se realizó el desfile anunciado como la Gran Parada Militar en Homenaje a las Glorias del Ejército chileno. Cabe preguntarse cuáles han sido esas supuestas glorias. ¿Las de la Independencia en una lucha por el poder que dejó como saldo la persecución y fusilamiento de los hermanos Carrera y sus seguidores? ¿La victoria en la Guerra del Pacífico creada a partir de intereses exclusivamente económicos? ¿La invasión devastadora del territorio mapuche en la Guerra de la Pacificación de Arauco? ¿La dictadura militar?

Este año, los mapuches fueron excluidos del Homenaje a las Glorias del Ejército chileno y sospecho que fueron ellos mismos quienes se negaron a participar en esa mitología nacional que hace de ellos y de los huasos que bailan la cueca, un artefacto de "lo autóctono".

Muy contradictoria es esta nación chilena que, de manera acomodaticia, incluyó en su imaginario a aquellos héroes de La Araucana que simbolizaban, desde una perspectiva española, los valores y virtudes establecidos por una gramática hegemónica obstinada en exacerbar las diferencias económicas, étnicas y genéricas. Como señala Etienne Balibar, el supuesto origen "araucano" de 
CATEDRAL TOMADA: Revista de crítica literaria latinoamericana / Journal of Latin American Literary Criticism Reseña. Lucía Guerra Cunningham, La ciudad ajena: Subjetividades de origen Mapuche en el espacio urbano. Santiago: Ceibo Ediciones, 2014. Premio Casa de las Américas (2013)

nuestra nación es una absoluta ficción que glorifica al personaje literario mientras discrimina contra los mapuches como seres de carne y hueso. Etnicidad ficticia de héroes no conmemorados en ninguna efeméride o día feriado de la nación. Tampoco los héroes "araucanos" son parte del Corpus Mysticum que da al ciudadano inmortalizado la calidad crística de lo eterno. (Lerner). En nuestra nación, ellos circulan como espectros mal ubicados o en la nada. La corporalidad de Caupolicán en la estatua de Nicanor Plaza está en el entorno europeizado del Cerro Santa Lucía y en el Club Hípico fundado en 1860 por una élite oligárquica que abogaba por la eliminación del pueblo mapuche asociado con la barbarie. El rostro de Colo-Colo sólo es visible a través del logo de un equipo de fútbol y tanto Galvarino como Lautaro carecen de todo cuerpo. Ellos son los fantasmas alegóricos de una abstracción discriminatoria que, aún hoy día, excluye al pueblo mapuche como sujeto histórico.

Dentro de un colonialismo interno totalmente enmascarado, la conspiración del silencio y la invisibilización del mapuche han sido las armas más efectivas en esa relación del Poder y el Saber, tan bien analizada por Michel Foucault. Cuántos chilenos saben que entre 1643 y 1881, por más de dos siglos, los mapuches constituyeron un pueblo autónomo e independiente del Imperio español y luego de la nación chilena. Cuántos chilenos saben que, en la llamada Guerra de la Pacificación de Arauco, el Estado chileno despojó al pueblo mapuche de un $90 \%$ de sus territorios. En un momento histórico en que ya no es posible silenciar e invisibilizar al pueblo mapuche, todo acto de resistencia en la actualidad, se deshistoriza para darle los oscuros visos del terrorismo y la afrenta a la patria.

En mi propia formación intelectual, la historia y la cultura mapuches fueron sinónimos de un espacio vacío. Con sólo una excepción: en el quinto año de la escuela primaria, una profesora nos hizo dibujar una ruca y nos explicó que, para dormir, los mapuches usaban una piedra grande, como almohada. Fue en Estados Unidos donde logré comprender que ignorar a los mapuches en Chile respondía a un mecanismo colonialista. Fue allí también donde conocí, con mucha 
admiración, su praxis histórica en un devenir teñido por la injusticia y el despojo aprendiendo parte de su cultura y una cosmovisión donde el Cuerpo, el Espíritu y la Naturaleza se unen, de manera consustancial, en el ámbito de lo sagrado.

Este es el contexto histórico y vivencial de La ciudad ajena. En este libro, me desvío de la perspectiva crítica predominante que le ha dado énfasis a lo textual a partir de la cultura mapuche y sus relaciones interculturales. Desde mi punto de vista, los espacios en sí y en diálogo con subjetividades marcadas por una clase social y un estatus étnico y genérico, constituyen un índice valioso. En los imaginarios urbanos de la literatura latinoamericana, la ciudad es el espacio de la memoria, del orden regulador y la transgresión, de la heterogeneidad en pluralidades conflictivas, del resquicio que permite relaciones ilícitas. Muy distinta es la relación de las subjetividades de origen mapuche con el espacio urbano. La ciudad posee una carga semántica anclada en la confrontación de dos voluntades: la del conquistador español empeñado en fundar ciudades como instrumentos de dominio y la del mapuche afanado en destruirlas. La ciudad en ruinas fue el símbolo de una victoria durante los primeros cien años en una guerra que no logró vencer a los mapuches. Y lograda la independencia del imperio español en 1643, la ciudad se convirtió en ese espacio más allá de la frontera habitado por el wingka usurpador.

En la literatura mapuche y debido a la inmigración a partir de 1930, la ciudad, generalmente ausente, es el espacio de un exilio cultural, de un desgarro con respecto al espacio propio, en una relación no dialéctica con la ciudad, ahora emblema de la nación y la cultura chilena que los excluye y menosprecia. En un acto de resistencia, esa subjetividad recuerda y escribe lo propio. Memoria y posmemoria se entrelazan para recuperar, a través de la escritura, el entorno ancestral.

Pero, como en todo exilio, esa recuperación sufre la contaminación de la cultura hegemónica y la noción misma de "lo mapuche" pasa por diversas rearticulaciones en una constante etnogénesis. Este flujo de identidades responde a una posición ideológica de un sujeto que, desde el espacio subalterno, reacciona 
CATEDRAL TOMADA: Revista de crítica literaria latinoamericana / Journal of Latin American Literary Criticism Reseña. Lucía Guerra Cunningham, La ciudad ajena: Subjetividades de origen Mapuche en el espacio urbano. Santiago: Ceibo Ediciones, 2014. Premio Casa de las Américas (2013)

ante el poder de la nación. Leonel Lienlaf en Despierta el ave de mi corazón, traza una trayectoria que va de la ciudad alienante a un retorno a lo ancestral mientras Elicura Chihuailaf propone el país de la memoria, como ese espacio intermedio entre la cultura mapuche y la cultura hegemónica. ("abrir los ojos y oír (hablar) nuestra (mi) verdadero lenguaje, pero que - ay realidad-ya no puede ser, para mis hermanos, propuesta de lenguaje único”. (76)

Tal vez el aspecto más interesante de la literatura mapuche es esta movilidad que engendra apropiaciones y reterritorializaciones en un Chile neoliberal que participa en la globalización. David Aniñir, desde la periferia urbana, recicla "lo mapuche" como un elemento degradado por la pobreza y en un amasijo de culturas. Juan Paulo Huirimilla pone en evidencia, a partir de la cantina y la ranchera mexicana, un amplio campo de intertextualidades culturales mientras Eliana Pulquillanca inscribe el activismo político que ocupa los espacios públicos de la ciudad en una performance que exhibe cuerpos y voces en rechazo a la otredad impuesta por la nación chilena.

Procesar lo ajeno para insertarlo en lo propio no es sólo un acto de resistencia, es el impulso del pueblo mapuche que no ha cesado de participar en una praxis histórica para defender sus derechos. 